\title{
E-commerce professional student satisfaction analysis of local university
}

\author{
Shuxin Guo ${ }^{1, a}$, Yuzhuo Song ${ }^{2, b}$, Chengli Zhao ${ }^{1, c}$ \\ ${ }^{1}$ School of Management Science and Information Engineering, Jilin University of Finance and \\ Economics, Jilin Changchun, China \\ ${ }^{2}$ School of Literature,South China normal university,Gudong Guangzhou,China \\ agsx0216@126.com, ${ }^{\mathrm{b}}$ 549757664@qq.com, ${ }^{\mathrm{c}}$ zhaocl069@163.com
}

\begin{abstract}
Keywords: colleges and universities;e-commerce satisfaction ; evaluation system.
\end{abstract}
Abstract. In this paper, by applying the theory of customer satisfaction and " students oriented " combination of the concept of talent cultivation, built e-commerce specialty in local universities student satisfaction evaluation model, and use the "designed e-commerce specialty in local colleges student satisfaction questionnaire "launched professional satisfaction survey. To receive the data statistical analysis, calculate the various satisfaction indexes. Investigation and analysis show that e-commerce professional guidance form, professional course setting and employment prospects have more significant effect on students' satisfaction. Aiming at these factors some suggestions were proposed.

\section{Introduction}

Customer satisfaction theory, first bud in the consumption psychology research in the early 20th century, With the rapidly development of market economy, customer satisfaction theory goes out of the ivory tower, entering the stage of practical research, covering economics, marketing, consumer psychology, econometrics, and many other fields. Customer satisfaction is a new strategy completely "customer oriented", meeting customer demand, letting customer satisfaction for the purpose.

Satisfaction research in the field of higher education in China began in the late 1990s, mainly from three aspects:

I First, the customer satisfaction theory in colleges and universities, mainly on the customer and the product definition of colleges and universities.

I Second, the study of customer satisfaction evaluation in colleges and universities, including the construction of evaluation system and evaluation method of exploration.

I Third, the empirical study of customer satisfaction evaluation in colleges and universities. Can be seen that the theoretical circle has already seen the customer satisfaction theory for the practical value of higher education, Claim is widely used in the field of higher education customer satisfaction theory, promote the overall development of higher education.

Electronic commerce is an emerging interdisciplinary that the integration of economic, management, law and computer technology. Using the student satisfaction evaluation system analyzed the student satisfaction research of e-commerce specialty in local colleges aiming to understand what the electronic commerce specialized students think of the professional teaching present situation, the structure of the curriculum system and teaching facilities and quality approval, clearing the expectations of students and what they actually get, providing powerful basis of The talent training scheme for late revision and improvement of teaching and quality improving.

\section{The construction of e-commerce professional student satisfaction evaluation system in local colleges and universities}

\section{A.The establishment of e-commerce professional student satisfaction evaluation system}

Established Four levels of measurement system, E-commerce professional student satisfaction is the general evaluation index which is the first level; At the second level includes the perception of 
e-commerce, the satisfaction of e-commerce professional education enlightenment, the satisfaction of the e-commerce professional teaching quality, job satisfaction, students' complain and students' loyalty,- six secondary indicators totally. Then spread the secondary indicators for the tertiary indicators including hardware facilities, quality of personnel service, professional export, etc. According to the characteristics of the indicators we transform 3 levels indicators into questionnaire, formed the fourth level of the evaluation index system. Shown in table 1 is the e-commerce professional student satisfaction evaluation index system.

Table 1:e-commerce professional student satisfaction evaluation index system

\begin{tabular}{|c|c|c|}
\hline First level & Secondary level & Tertiary indicators \\
\hline \multirow{16}{*}{$\begin{array}{l}\text { Electronic } \\
\text { commerce } \\
\text { specialized } \\
\text { student } \\
\text { satisfaction }\end{array}$} & \multirow{3}{*}{$\begin{array}{l}\text { the perception of } \\
\text { e-commerce }\end{array}$} & When to know the electronic commerce \\
\hline & & The satisfaction of knowing electronic business \\
\hline & & The satisfaction of the way to acquire electronic \\
\hline & \multirow{3}{*}{$\begin{array}{l}\text { the satisfaction of } \\
\text { e-commerce } \\
\text { professional } \\
\text { education }\end{array}$} & The satisfaction of the time to get professional \\
\hline & & githaance sactisfaction of the way to get professional guidance \\
\hline & & professional competition \\
\hline & \multirow{4}{*}{$\begin{array}{l}\text { the satisfaction of } \\
\text { the e-commerce } \\
\text { professional } \\
\text { teaching quality }\end{array}$} & The satisfaction of the curriculum provision \\
\hline & & The satisfaction of the hardware facilities \\
\hline & & The satisfaction of the teaching staff \\
\hline & & The satisfaction of the ability training \\
\hline & \multirow{3}{*}{ job satisfaction } & The Satisfaction perception of the career prospects \\
\hline & & The satisfaction of the career salary \\
\hline & & The satisfaction of the employment units \\
\hline & students'complaint & Students grumble or complain \\
\hline & \multirow{2}{*}{ students' loyalty } & The possibility of consumption once again \\
\hline & & The possibility of praise for others \\
\hline
\end{tabular}

The Heading level 2 is left-justified, not bold, with initial caps and numbered using Times New Roman 10 point, with no blank line above or below the heading. Here your text continues...

\section{B. E-commerce professional student satisfaction evaluation indicators of quantitative}

Because the Likert scale is relatively easy to design and processing, and surveyed students easier to understand, this article uses the five level order Likert scale. This paper adopts the five level attitude scale including three kinds, first, used to measure satisfaction directly, including very dissatisfied, not satisfied, satisfied, very satisfied, the corresponding assignment are 1, 2, 3, 4, totally 12 questions; second, used to measure the degree of management service desired by the students in colleges and universities and whether meet the students' needs, including far cry, fall short of, basic meet , beyond, the corresponding assignment are 1, 2, 3, 4, totally 6 questions; third, used to measure the possibility that students continue to study at the university and praised his Alma mater to others, including won't, maybe, might, certainly, the corresponding assignment of $1,2,3,4$, totally 2 questions; last, designed 1 question to know the situation that students' complaints, including reflect an opinion about the professional talent question, privately complain, never complained the corresponding assignment are $1,2,3$.

\section{The weight determination of e-commerce professional student satisfaction evaluation index}

Student management degree of satisfaction evaluation index system reflects the university electronic business professional quality and characteristics of talent cultivation, however, the changes of each evaluation indicator how to effluent students' satisfaction is different.[3] But weight can be 
the important measure of influence degree. According to the characteristics of the objectivity of the factor analysis method is stronger, this research adopts the factor analysis method to determine each indexes' weight in electronic commerce specialized student satisfaction. Based on the data output of the factor analysis use a common degree percentage method calculated the weight of indicators at all levels.

\section{E-commerce professional student satisfaction— the multi-target weighted average method}

Usually, in the majority of customer satisfaction evaluation adopts the multi-target weighted average method.[4] Formula of student satisfaction is:

$$
\mathrm{X}=\sum_{\mathrm{i}=1}^{\mathrm{L}} \mathrm{W}_{\mathrm{i}} \wedge_{\mathrm{i}}\left(0<\mathrm{W}_{\mathrm{i}}<1: \sum_{\mathrm{i}-1}^{\mathrm{L}} \mathrm{W}_{\mathrm{i}}=1\right)
$$

In the formula above : $\mathrm{X}$ means student satisfaction, Wi means the weight of the factor ' $\mathrm{i}$ ', $\mathrm{Ai}$ means the average of all the respondents about the evaluation factors ' $i$ '.

\section{E. E-commerce professional student satisfaction model fitness analysis}

This paper based on $\chi^{2}, \chi^{2} / d f$, the matching fit degree (GFI), adjusted to fit (AGFI), average root mean square (RMSEA) approximation error non reference fit (NNFI), incremental fit (IFI), the whole of the model goodness of fit test. The specific numerical fit condition and E-commerce professional student satisfaction model are shown in table 2:

Table 2:E-commerce professional student satisfaction model fitness comparison table

\begin{tabular}{|l|l|l|}
\hline Adaptation degree index & Ideal targets & satisfaction index \\
\hline$x^{2}$ & $\begin{array}{l}\text { he smaller the } \\
\text { better }\end{array}$ & 121.560 \\
\hline$x^{2} / d f$ & $<3$ & 2.481 \\
\hline GFI & $>0.9$ & 0.941 \\
\hline AGFI & $>0.9$ & 0.906 \\
\hline RMSEA & $<0.08$ & 0.071 \\
\hline TLI & $>0.9$ & 0.949 \\
\hline IFI & $>0.9$ & 0.962 \\
\hline CFI & $>0.9$ & 0.962 \\
\hline
\end{tabular}

From the table we can see that the student satisfaction, evaluation model established by this research. Having a better fit. Objective response to the actual situation of samples.

\section{The empirical study}

\section{A. Data analysis}

The questionnaire collected all valid data enter the computer, and process statistical analysis by SPSS11.0.First of all, using descriptive analysis on the four dimensions of e-commerce distribution professional student satisfaction 、 the situation compared with the students expected and the situation meet the needs of the students. Then, using the data output of the factor analysis, applying a common degree percentage method to calculate weight of the indexes at all levels, and calculating each index with weighted average method the same as overall student satisfaction. The results are shown as table 3 E-commerce professional undergraduate students' satisfaction to the professional enlightenment in local colleges, professional quality of teaching and professional obtain employment prospect these three indicators of the degree are $82 \%, 78.9 \%$ and $82 \%$. The overall student satisfaction was $86.4 \%$, which is consistent to the other three service satisfaction.

\section{B. Conclusion}

This paper also quadrant diagram analysis on the overall management of assessment indicators. Results show that the overall impression of e-commerce professional and general feelings towards 
professional enlightenment is located in the first quadrant, weight heavier and student satisfaction is higher, this is the school's advantage.

The feeling of the teaching quality of professional and employment prospects perception is located in the second quadrant, this has a great influence on students' satisfaction, but the student evaluation of the satisfaction is low, which Is a weak link in specialty construction and personnel training, we have to strengthen the discipline construction of e-commerce, strengthen the teaching process monitoring in the future work, So as to improve the quality of teaching and talent training quality.

Table 3 Local university electronic commerce specialized student satisfaction calculation data sheet

\begin{tabular}{|l|l|l|l|}
\hline Indicators & weight & average & CSI \\
\hline Overall Professional education satisfaction & 0.296 & 2.903 & 0.859 \\
\hline Professional enlightenment satisfaction & 0.261 & 3.141 & 0.820 \\
\hline Professional teaching quality satisfaction & 0.241 & 3.272 & 0.789 \\
\hline Professional obtain employment prospect & 0.212 & 2.965 & 0.629 \\
\hline USSI (\%) & 1.000 & 3.129 & $(86.4 \%)$ \\
\hline
\end{tabular}

\section{Conclusions}

College students want their college be run really as the idea that 'all for students, to students of all', requiring college getting to know the needs of the students in major construction, course construction, personnel training, employment demand and other aspects, to understand the needs of the society, more listen to the opinions of the students and the social from all walks of life advice。Student satisfaction is a very useful management tool, Colleges and universities can implement the strategy of students satisfied with, the application of "student satisfaction" professional evaluation, and based on this evaluation, formulate the scheme to solve the problem, directing the work of a professional construction. At the same time we also realize the student satisfaction research is school professional decisions instead of college professional decision .Students don't have received specialized training in assessment, the evaluation standards tend to be their personal background, personality, the influence of such factors. There needs to be targeted in future research work were analyzed, and try to rule out or eliminate adverse and misleading factors.

\section{Acknowledgements}

This work was financially supported by the National Science Education "Twelfth Five Year Plan" 2011 year Key Project of Ministry of Education( Title: A survey on the satisfaction degree of service of higher education for College Students; Grant No. DIA110262); Jilin province education science "Twelfth Five Year Plan" Grant No.GH14219、GH150287; Jilin province education science "Thirteen Five Year Plan"Grant No.GH16249; Jilin province Research focus of higher education teaching reform in 2016.

\section{References}

[1] Fornell C. A Natinal Customer Satisfaction Barometer: The Swedish Experience[J]. Journal of Marketing,Vol.6-21(1992),p.56

[2] Lin Zhao, Shi Jinghuan, Wang Peng, Wang Wen, Xu sweet. [J]. education in Tsinghua University study plan school types and regional differences in the quality of higher education, Vol.5(2012),p.9-22.

[3] [USA] Derek. Ellen. Customer satisfaction data analysis [M]. Dalian: version club of northeast university of finance and economics, 2005: 1 - 4 
[4] Chen Limei Lu Zifang. An empirical study of e-commerce professional student satisfaction [J]. Journal of southwest normal university (natural science edition), Vol.4(2008),p.161-164.

[5] Schreiber,JB.,Nora,A.,Stage,F.K.,Barlow,E.A.,\&King,J.Reporting structural equation modeling and confirmatory factor analysis results: A review.[J].The Journal of Educational Research,Vol.99(2012),p.323-337

[6] Schreiber, J.B.Core reporting practices in structural equation modeling.[J].Administrative Pharmacy, Vol.4(2008),p.4:83-97 